\title{
Judging Books by Their Covers: Managing the Tensions between Paperback and Clothbound Purchases in Academic Libraries
}

\author{
Alan W. Aldrich
}

\begin{abstract}
Book purchases are a significant portion of an academic library's budget. Selecting paperback rather than hardback editions can stretch collection development dollars. This study examines the collection development statements of forty-six academic libraries regarding the selection of paperback editions. Some libraries provide vague guidance, while others identify specific price differentials between the costs of paperback and hardback editions as a decision criterion. A new method of using price difference ratios is proposed and tested using four academic disciplines. The results suggest that libraries using such ratios can achieve greater control over costs while meeting collection development goals.
\end{abstract}

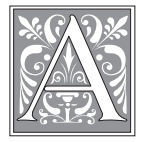

cademic libraries in the United States spent over \$112 million dollars to acquire books in 2006. This represents 15 percent of the overall acquisition budget for these libraries. ${ }^{1}$ While periodical costs comprise almost 33 percent of academic library acquisition budgets, book expenditures remain a considerable expense that requires careful monitoring and control if libraries are to maintain their collections. As is the case with periodicals, the cost of academic books is rapidly escalating. These costs increased 6.4 percent in 2005 alone. ${ }^{2}$

Some academic libraries are purchasing monographs in paperback format as a means of managing the tension between escalating costs and the need to develop and maintain collections that serve the needs of their patrons. An examination of collection development statements with attention to paperback selection processes can provide insights as to how and under what conditions academic libraries select paperback over clothbound editions. The analysis presented here examines the content of collection development statements from academic libraries to identify and articulate the underlying reasons for their book purchase decisions. An alternative to current practices as represented in these statements is offered and a metric for making paperback purchasing decisions is presented.

\section{Why Choose Paper Over Cloth?}

Price is an obvious reason why an academic library might consider paperbacks

Alan W. Aldrich is an Assistant Professor in the I.D. Weeks Library at University of South Dakota; e-mail: aaldrich@usd.edu. The author would like to thank Carol Leibiger for her thoughtful comments and insights on multiple drafts of this paper and two anonymous referees for their work in shaping the end result. 
over clothbound editions. ${ }^{3}$ In 2006 the average price for clothbound texts in the sciences, social sciences, and humanities was $\$ 62.15^{4}$ compared to $\$ 37.01$ for paperback editions, ${ }^{5}$ excluding mass-market books. Additional reasons for considering paperbacks include the improved quality of paperback editions, the ability to add supplemental bindings to paperback editions (especially when heavy use is expected), and the fact that the physical life span of paperback editions often exceeds the intellectual life span of their content.

The quality of paperback editions has greatly improved over the years through using acid-free paper, stronger and higher-quality bindings, and the higher quality presses that are now producing paperback editions alongside hardcover editions. ${ }^{6}$ Many libraries enhance their paperbacks through rebinding or using reinforcing material to increase their durability under conditions of expected heavy use.?

The intellectual life span of information is rapidly decreasing. Slote points out that information in fields such as economics or technology and applied sciences is considered out of date after just five years. ${ }^{8}$ At the same time, Slote also argues against weeding a book from a university library collection unless it has not been checked out at least once in a twenty-year time span. Evidence presented in a series of studies focused on the same university library collection strongly suggests that paperback editions will last sufficiently to be in a collection for twenty years or more with use. ${ }^{9}$ Jenkins recommends that college libraries shift their purchasing decisions from hardcover to almost exclusively paperback editions. ${ }^{10}$ The next section of this paper identifies how academic libraries make decisions regarding the purchasing of paperback editions through a content analysis of collection development statements.

\section{Collection Development Statement Data}

Goal- and purpose-driven statements crafted by institutions provide a privi- leged window into organizational thinking and intent. ${ }^{11}$ Collection development statements articulate the goals and purposes of the library in building and sustaining a collection. ${ }^{12}$ Collection development statements from academic libraries of different sizes were gathered and analyzed to identify why and under what conditions paperback editions are purchased for academic library collections.

These collection development statements were acquired through a Webbased search. Google's advanced search function was used to identify the phrase collection development along with either one of the terms paperback or paperbacks. The search results were restricted to the Internet domain suffix .edu and to the English language.

Collection development statements were culled from forty-six academic library Web sites based upon the explicit mention of policies regarding the purchase of paperback editions. Phrases describing the acquisition of paperback editions were copied from each collection development statement. Categories were coded as they emerged from the content. Because the phrases used to describe different aspects of collection development are relatively uniform as they apply to the acquisition of paperback editions, the categories were stable and easily identifiable. Each category was fully developed after analysis of the initial twenty collection development statements. Since the intent was to obtain a range of statements that expressed the different aspects of collection development and no new categories were emerging, data collection was halted after forty-six statements had been analyzed.

\section{Purchasing Decision Metrics}

Academic libraries employ a limited number of metrics when considering the purchase of cloth or paperback editions. A recent typology of these metrics identified four different orientations ranging from a cloth-only purchasing policy to 
a policy that explicitly favored selecting paperback editions for most purchases. ${ }^{13}$ Of the forty-six libraries in this study, ten libraries favor the purchase of paperback over cloth editions, while twenty-nine libraries identify cloth editions as their preferred format. Even though the majority of libraries in this study favor purchasing monographs in clothbound editions, almost all of these libraries provide some guidelines for selecting paperback editions. The metrics most often mentioned when considering paperback editions include the purchase price (twenty-seven libraries), the amount of use a book might receive (nineteen libraries), the lasting value of the content (ten libraries), and the quality of the press and/or paper (three libraries).

The role played by price in the selection decisions of academic libraries is evident in the following statements:

- "Paperback monographs for the regular collection are acquired when hardback editions are not available or when there is a significant price difference between the hardback and paperback editions." (Babson College) ${ }^{14}$

- "Hardbound monographs will normally be selected over paperbacks. Paperback monographs for the regular collection will only be acquired when hardback editions are not available or hardback cost is prohibitive." (Indiana University-Kokomo ${ }^{15}$

- "For reasons of economy, trade paperbacks are sometimes purchased." (University of Arkansas at Little Rock) ${ }^{16}$

- "To increase the purchasing power of the materials budget, paperback monographs will be acquired when there is a significant price difference between the hardback and paperback editions." (LSU and A\&M College) ${ }^{17}$

The Babson College collection development policy identifies two themes common in such documents. The first theme is the acquisition of paperbacks in the absence of cloth or hardback editions. This theme is present in sixteen of the library collection development statements analyzed for this paper. Including this type of statement in the collection development policy introduces a presumption that favors cloth over paperback editions. Indiana University at Kokomo also makes its preference for cloth explicit while allowing for the purchase of paperbacks when hardcover editions are not available.

The second theme focuses on the cost differential between the prices of paperback and clothbound editions. Twenty-seven libraries in this study identified cost differentials as reasons for considering paperback over clothbound editions. Both Babson College and LSU and A\&M College identity a "significant price difference" between the cost of the paperback versus clothbound edition as a decision criterion. The statement made by the University of Arkansas at Little Rock offers an explicit economic justification for selecting paperback editions without providing any further guidance. The qualifier sometimes suggests that purchasing trade paperbacks is not a common choice for this library.

While price is the dominant consideration for academic libraries when deciding to purchase a paperback edition, factors such as the expected use of a title, the lasting value of the work's content, and the reputation of the publisher can influence the decision-making process as seen in the following statements:

- "The library reserves the right to choose between hardcover and paperback when both are available; however our preference is to purchase hardcover whenever feasible. If the cost of the hardcover edition is significantly higher, we may purchase the paperback instead, depending on the demand for and collection level of the title." (Stonehill College) ${ }^{18}$

- "Where there is an option of paperback or hardback, the choice is based upon expected use, lasting value of content, and cost differential. As a general rule, hardback or paperbacks with library bindings are preferred over consumer market paperbacks." (North Georgia College and State University $)^{19}$ 
- "The exception is where there is an excessive price difference between hardback and paperback. In making a determination, the Library will also consider the long-term value and expected use of the title." (University of Hawaii at Hilo) $)^{20}$

- "The Library will consider purchasing a paperback edition, especially when this edition is considerably less expensive than a hardback edition and when a publisher of high quality has printed the title." (University of Oregon) ${ }^{21}$

Each of these libraries favors the purchasing of hardcover books when possible. At the same time, these libraries allow for the acquisition of paperback editions based upon price and additional factors. Stonehill College may purchase paperback editions based upon perceived demand and the collection level of the title. Conversely, they may not make a paperback purchase even though the price difference alone favors such a decision. North Georgia College and State University identifies price after long-term value and expected use without indicating any priority of these factors in its selection processes. Both the University of Hawaii at Hilo and the University of Oregon, respectively, base their decisions to purchase paperback editions on price moderated by additional factors.

Many libraries identify additional conditions such as binding or specifying preservation requirements for paperback editions, especially when the library already favors clothbound editions. In this sample, twenty libraries included statements that specifically addressed binding and/or reinforcing paperback editions ranging from selected books (i.e., reference or heavy-use titles) to all paperback editions added to their collections.

- "The library, if there is a cost saving, will acquire books in paperback over hardback if the paper quality is sufficient to ensure long term use. The library will not routinely have all paperbacks bound but rather will protect the covers with a
Mylar cover applied locally." (College of Wooster) ${ }^{22}$

- "Paperback monographs for the regular collection are acquired only when hardback editions are not available. The Libraries generally bind a paperback if it is the only edition available." (Baylor University $)^{23}$

That so many libraries would have some sort of binding/reinforcement statement in their policies makes sense, given the preference many libraries give to cloth editions due to expected longevity. Of the twenty libraries that have binding statements in place, fourteen libraries also explicitly favor clothbound editions as their preferred format.

The majority of collection development statements analyzed so far have been from libraries at colleges (for instance, Babson College), medium-sized universities (such as Baylor University), or regional campuses of a larger state institution (for example, University of Arkansas at Little Rock). While most of these schools favor clothbound editions, they each have provisions in which paperback editions might be added to their collections. This, along with the fact that price figures so prominently in the decision to purchase paperback editions, suggests the premise that an academic library's collection is or ought to be archival in nature is being modified by pressures from increased acquisition costs. The next section examines the collection development statements from the libraries at the largest universities included in this study.

- "Books/monographs are normally collected in clothbound editions except when items are available only in paperback editions." (University of Notre Dame $)^{24}$

- "Current Monographs. This material is usually acquired in hardcopy. Hardbound editions are preferred to paperback, where available." (University of South Carolina) ${ }^{25}$

- "Paperbacks will be purchased when cloth binding is unavailable and the resource meets all other collection 
development criteria. Mass market paperbacks will not generally be purchased. If high use and long-term retention is anticipated paperback resources will be bound. The circulation, reference, collection management and technical services units are jointly responsible for determining which paperbacks to bind." (Florida A\&M University) $)^{26}$

What is apparent in each of these large university library approaches in developing their collections is the fact that clothbound editions are always preferred except when paperback editions represent the only choice available. Florida A\&M University is more restrictive by stipulating that all other collection criteria must be met before an item will be purchased in paper format. Implicit in this is the notion that only some criteria must be met when purchasing a clothbound edition. The fact that these large academic libraries insist on purchasing only clothbound editions whenever possible is consistent with the archival orientation of major university libraries. This orientation is made possible in part through their considerably larger acquisition budgets. However, the largest academic libraries are not immune from the cost pressures faced by their smaller brethren. The Collection Development Council of the Yale University library has discussed moving toward paperback preference as early as 2001 in response to increased costs, while acknowledging many other factors must be considered..$^{27}$

\section{Strategic Ambiguity}

The collection development statements examined so far take advantage of the strategic ambiguity inherent in language in spite of local differences in their forms of expression. None of the statements listed above that highlight price as a key criterion specify the price differential that will trigger a paperback purchasing decision. Phrases such as "considerably less expensive" or "significant/excessive price difference" are underdeterminate, relying upon local decision makers to make a subjective decision regarding price.
This ambiguity grants considerable agency to librarians selecting volumes for the library's collection, even when the phrasing of the conditional statement is strong or unambiguous as to the organization's intent. Phrases such as "will consider purchasing a paperback edition" are not as strong as if-then conditional statements, and these ambiguities increase the degree of agency enjoyed by book selectors. Libraries that identify additional factors such as the expected use or value of the content make the selection process even more subjective.

Agency or freedom to act created through strategically ambiguous collection development statements can be a powerful and useful tool for libraries as organizations. Strategic ambiguity also has hidden costs. Some of the costs associated with strategically ambiguous collection development statements include a lack of uniformity between selectors and the inability to measure and/or control savings achieved through selection of paperback over clothbound editions.

\section{Dual Format Price Data}

Some academic libraries try to reduce uncertainty and ambiguity in the collection development process by identifying specific price metrics. This section considers the impact specific price metrics have on developing a library's collection. These metrics will be examined using a data set of dual-format book prices obtained from six months of book reviews published in The Chronicle of Higher Education. The number of books that would be purchased in either paperback or cloth formats using these price metrics is calculated and the results checked for consistency with the collection development statement of the libraries included in this study. The ways that these collection development statements manage price is problematic. An alternative price metric that addresses these problems is proposed and tested.

Academic books published simultaneously in cloth and paperback editions were identified from reviews contained 
in The Chronicle of Higher Education. The list prices for both cloth and paperback editions were initially collected over a fifteen-week period beginning on 5 May 2006. Four disciplines had the greatest frequency of dual publication texts. The analysis was continued, selecting only titles in Anthropology, History, Political Science, and Sociology. All dual-published books in these disciplines were identified along with their prices for a twenty-six week period from 5 May to 27 October 2006. The distributions of frequencies for dual publication texts in each subject category are presented in table 1 .

The price differentials between the paperback and cloth editions were calculated for each book in the data set along with the average price differences within each category. These average differences are presented in table 2 .

There appears to be little variation in the average price differences between paperback and cloth editions in anthropology, history, and political science. As subsequent analysis will demonstrate, there is considerable variation between disciplines when different price ratios are considered.

\section{Explicit Price Metrics}

Three libraries in this study identified specific price differentials that, once exceeded, would trigger the purchase of paperback over clothbound editions. Their collection development statements are presented below:

- “Books/Monographs are normally collected in clothbound editions except

\begin{tabular}{|l|l|}
\multicolumn{2}{|c|}{ TABLE 1} \\
\multicolumn{1}{|c|}{$\begin{array}{c}\text { Frequency of Books in each } \\
\text { Subject Discipline }\end{array}$} \\
\hline \hline Anthropology & $\mathrm{n}=45$ books \\
\hline History & $\mathrm{n}=72$ books \\
\hline Political Science & $\mathrm{n}=56$ books \\
\hline Sociology & $\mathrm{n}=45$ books \\
\hline Total number of books & $\mathrm{n}=218$ books \\
\hline
\end{tabular}

when items are available only in paperback editions. The exception is when the price differential between the clothbound edition and paperback edition is deemed to be excessive (generally, if the clothbound edition costs at least $\$ 10.00$ more than the paperback edition). In this case, the paperback edition will be purchased and will be sent to the bindery." (Drake University) ${ }^{28}$

- "Paperbacks will be selected over hardbound editions if the cost of the paperback edition is substantially (\$20.00) less than the cost of the hardbound edition." (Colgate University) ${ }^{29}$

- "Hardcover bindings are preferred because of their durability. Paperbacks are purchased when a suitable hardcover edition is not available or when the price of paperback is at least \$25 less than the hardcover and high use is not anticipated." (Christopher Newport University)

The average price in 2006 for academic cloth editions was $\$ 62.15$, compared to an average price of $\$ 37.01$ for paperback editions. ${ }^{31}$ The overall average price differential of $\$ 25.14$ exceeds each of the three price differentials specified in these

TABLE 2

Average Price Differences within each Category

\begin{tabular}{|l|c|c|c|}
\hline \hline \multicolumn{1}{|c|}{ Category } & Paperback & Cloth & $\begin{array}{c}\text { Price Differential/ } \\
\text { Ratio }\end{array}$ \\
\hline Anthropology & $\$ 24.81$ & $\$ 66.82$ & $\$ 42.01 / 2.69: 1$ \\
\hline History & $\$ 24.99$ & $\$ 66.82$ & $\$ 42.41 / 2.67: 1$ \\
\hline Political Science & $\$ 25.53$ & $\$ 68.58$ & $\$ 43.05 / 2.68: 1$ \\
\hline Sociology & $\$ 24.95$ & $\$ 70.18$ & $\$ 45.23 / 2.81: 1$ \\
\hline Overall average & $\$ 25.07$ & $\$ 67.60$ & $\$ 43.17 / 2.70: 1$ \\
\hline
\end{tabular}


collection development statements. This suggests that a large portion of books selected by these libraries will be paperback editions. The gap in price between the paperback and cloth editions presented in table 2 for each of the disciplines collected in this study is even larger than the overall average price differences, thus reinforcing the belief that paperback editions are favored by these library collection development statements.

This bias toward paperback editions created by these price differentials is problematic for these libraries, given the overall content of their collection development statements. Drake University explicitly favors clothbound editions, probably for their perceived durability. This analysis is supported by the fact that Drake University sends paperback editions to be bound after their purchase.

Christopher Newport University is even more explicit in its bias in favor of clothbound editions. Durability is a primary consideration as stated in its collection development policy. The $\$ 25.00$ price difference cited by Christopher Newport University as a reason for considering paperback purchases is phrased as a conditional statement. This cost difference, coupled with the anticipated lack of high usage, is what triggers the decision to purchase a title in the paperback format. Colgate University, while not indicating a direct preference for cloth editions in its collection development statement, indicates that the cost difference is treated as "substantial" before paperback editions are purchased. This suggests cloth editions are the initial choice for Colgate University's collection development efforts.

The price differentials specified by these three libraries were compared to the price differentials for each book in the data set. The smallest price difference between the paperback and cloth prices was a political science book with a $\$ 15.00$ price differential. Drake University would have purchased 100 percent of their books (218 books) in paperback format using a price differential of $\$ 10.00$ or greater between the paper and cloth prices in the four disciplines presented in this data set. Colgate University would have purchased 97 percent of their titles (211 books) in paperback format using their $\$ 20.00$ or greater price differential. Only seven books would have been purchased by Colgate University in cloth format, including two books with price differentials of $\$ 20.05$ and $\$ 20.25$ respectively. Christopher Newport University specified the highest price difference of $\$ 25.00$ between the paper and cloth edition prices. As would be expected, fewer books were purchased in paperback formats. However, if the expected-use criterion is ignored for the sake of this analysis, Christopher Newport University would have purchased 92 percent of their texts (200 books) in paperback editions, adding only eighteen clothbound books to their collection from this set of titles. Use of the fixed-price differential by all three libraries would result in the majority of books being purchased in the paperback format in spite of the overt preference expressed in each statement for clothbound books, all other factors notwithstanding.

Drake University sends its paperback editions to be bound. The cost of treating paperbacks needs to be factored into the cost differential. A stiff cover that preserves the cover art can be added for just under $\$ 6.00$ per volume in 2008 dollars. ${ }^{32}$ Additional options, especially if very heavy use is expected, include a complete rebinding and new covers with costs ranging from around $\$ 8.00$ to $\$ 15.00 . .^{33}$ Depending on the services purchased, Drake University could realize a small savings per volume using its price differential. Both Colgate University and Christopher Newport University would realize savings even after treating their paperback editions. Many libraries that bind paperbacks use a deferred binding method of waiting until the volume has received a specific number of uses before receiving treatment. This reduces costs and increases savings. 
Two problems are immediately apparent with purchase metrics that specify a fixed-price differential. First, variation exists among these libraries in terms of what constitutes a significant price difference between paperback and cloth editions. Even though the collection development statements indicate a marked preference for clothbound editions, employing these metrics produces the opposite result, increasing the number of paperbacks added to a collection under the guise of substantial price differences. Second, fixed-price differentials are problematic because prices do not remain stable over time. Inflation, especially in the publishing industry, makes any named price obsolete within the time frame of a year. The $\$ 25.00$ price differential instituted by Christopher Newport University in 2001 would probably have resulted in fewer paperback book purchases than the 92 percent figure derived from our data set using 2007 prices. However, libraries that identify specific price differentials as part of their collection development statements must reconsider the price point on an annual basis to ensure the "significant" price difference remains significant in terms of their collection development goals.

\section{Using Ratios as Price Differentials}

Two libraries whose collection development statements are part of this study use a different approach in identifying price differentials. Haverford College and Assumption College use ratios to identify the price differential that would trigger consideration of a paperback purchase decision.

- "The Library acquires monographic material in cloth bindings and on paper that meets preservation standards; in cases when the price difference between cloth and paperback binding is significant, say, $100 \%$ or more, and projected use does not argue for acquiring the cloth edition, the library acquires the paper edition and treats it in-house to increase its life expectancy." (Haverford College, February) $)^{34}$
- "The paperback format will be ordered unless at least one of the following situations applies: A hardcover copy can be acquired for less than twice the cost of the paperback. The Member of the faculty or the liaison ordering the book specifies a format." (Assumption College) ${ }^{35}$

Haverford College and Assumption College both use a 2:1 ratio for the price differences between paperback and clothbound editions. Using ratios rather than identifying fixed-price differences resolves the problems associated with inflation or changing prices because ratios remain stable regardless of the direction of the price movements. The only condition under which a ratio can become problematic occurs when there is a different rate of price movements for paperback and cloth editions. Evaluating the effect of the selected price ratios as part of a regular examination of the library's collection development policy should resolve this issue if it arises.

Since the average price differential between paperback and cloth editions expressed as a ratio is considerably higher than the 2:1 ratio employed by Haverford and Assumption Colleges, both colleges ought to make the same number of paperback purchases. Paperbacks would constitute a significant majority of their book purchases if the price ratio is strictly applied without adding the subjective conditions such as the expected use of an edition.

These assumptions were tested using the data set of dual printed book prices. The price differentials between paperback and cloth editions in this data set were calculated and compared against a 2:1 ratio of price differentials. Any title with a ratio of 2:1 or less was treated as a cloth edition purchase. There are fourteen titles where the cloth price is equal to or less than the 2:1 ratio to the paperback price. Both Haverford and Assumption colleges would have purchased 204 books in paperback editions or 93.5 percent of the 218 titles available in dual editions. There were three books where the ratio was between 2.01 and 2.04 
to 1 . Treating these as cloth rather than paperback purchases would result in 92.2 percent of all books in the sample set being treated as paperback purchases.

Haverford College's collection development statement suggests a preference for clothbound over paperback editions. The statement begins with the phrase "material in cloth bindings and on paper that meets preservation standards." This phrase is immediately followed by the qualifying statement that introduces the conditions under which paperback editions can be considered. The 2:1 price difference ratio used by Haverford College when considering paperback editions is qualified by conditions of expected use. Furthermore, paperback editions receive binding treatment after their acquisition. Given that Haverford College appears to prefer cloth editions for its collection, using a 2:1 price difference ratio may be viewed as overly generous since it favors paperbacks over cloth editions.

Assumption College, which is on the opposite end of the cloth/paperback continuum, expresses a clear preference for purchasing paperback editions in its collection development statement. Using a 2:1 ratio that favors paperback purchases is consistent with its collection orientation. However, it is not clear from the twenty-nine library collection development statements that explicitly identify cloth editions as the preferred format whether a 2:1 ratio would be appropriate or acceptable. The final sec- tion of this paper examines the impact different price ratios would have on the number of books a library would select in paperback format if price were the only consideration being applied.

\section{Ratio Analysis}

Because the 2:1 ratio results in paperback editions from this data set being purchased over 92 percent of the time, and the average ratio of cloth to paperback prices as reported in table 1 is considerably higher (about 2.7:1), new ratios were calculated between 2.5:1 and 3:1, using .10 increments. A binary code was used, with each title exceeding the identified price ratio coded as a 1 and titles failing to exceed the given ratio coded as 0 . The number of titles exceeding the specific ratio were summed and divided by the $\mathrm{N}$ size for each category of books in Anthropology, History, Political Science, and Sociology. This value represents the percentage of books that would be purchased in paperback editions if the given ratio was employed as the sole decision criteria in a library's collection development statement. Because the other factors listed for consideration such as anticipated use or quality and longevity of the content require subjective judgments, this analysis is based solely upon price as the decision criteria. The additional factors, when applied, should result in smaller numbers of paperback books being added to the collection for each ratio being tested. The results are presented in table 3 below.

\begin{tabular}{|l|c|c|c|c|c|c|}
\hline \multicolumn{7}{|c|}{ TABLE 3 } \\
\hline Price Differential Ratios Applied to Purchasing Decisions \\
\hline \hline Category & Ratio $>\mathbf{2 . 5}$ & Ratio $>\mathbf{2 . 6}$ & Ratio $>\mathbf{2 . 7}$ & Ratio $>\mathbf{2 . 8}$ & Ratio $>\mathbf{2 . 9}$ & Ratio $>\mathbf{3 . 0}$ \\
\hline $\begin{array}{l}\text { Anthropology } \\
\text { (n=45 books) }\end{array}$ & 33 books & 27 books & 20 books & 16 books & 15 books & 15 books \\
$33 \%$ & $60 \%$ & $44 \%$ & $35.5 \%$ & $33 \%$ & $33 \%$ \\
\hline $\begin{array}{l}\text { History } \\
\text { (n=72 books) }\end{array}$ & 48 books & 40 books & 28 books & 25 books & 23 books & 21 books \\
\hline $\begin{array}{l}\text { Political Science } \\
\text { (n=56 books) }\end{array}$ & 37 books & 29 books & 20 books & 18 books & 14 books & 12 books \\
\hline $\begin{array}{l}\text { Sociology } \\
\text { (n=45 books) }\end{array}$ & 38 books & 29 books & 26 books & 23 books & 19 books & 14 books \\
\hline
\end{tabular}


Using a ratio of 2.5:1 as the decision metric would result in 66 percent of political science titles and 67 percent of history titles purchased in paperback editions. Conversely, 73 percent of anthropology titles and 84 percent of sociology titles would be purchased in paperback editions using the 2.5 ratio. This degree of variance between the subject disciplines was not evident from the average price differences presented in table 2 .

Increasing the price difference ratio to 2.6 results in a steep decline of the titles that would be selected in paperback for each of the four subject areas. Anthropology, history, and political science would have paperbacks selected 50 percent of the time if a ratio between 2.6 and 2.7 were used. Sociology would favor paperbacks in 50 percent of its purchasing decisions if the ratio were between 2.8 and 2.9 times the price difference. Using a ratio of 3:1 would still result in 29 percent of titles being selected in paperback editions for anthropology, history, and sociology and 21 percent of the titles for history.

\section{Discussion}

Academic libraries appear to be open to the inclusion of paperback editions into their collections, but not necessarily as a first choice. The language contained in many academic library collection development statements clearly favors hardbound editions over paperbacks, except when price alone or price along with additional criteria, such as the quality of press/bindings, comes into play. However, as this analysis demonstrates, there are considerable problems in attempting to operationalize current practices as represented in these library collection development statements. These problems include strategic ambiguity and using fixed-price differentials as metrics to identify when monographs should be purchased in paperback formats.

Strategically ambiguous language used in many collection development statements grants considerable agency to the librarians selecting texts while avoid- ing identification of what constitutes a significant price difference. Guidance is provided, but no real control is found in these ambiguous collection development statements. Ambiguous, although perhaps not intended in a strategic sense, is the "expected use" of a monograph as a selection format criterion. The concept of expected use is not defined in such a way that it can be clearly operationalized. Librarians as professional bibliographers have to rely on their tacit knowledge gained through experience as to which items can be expected to receive heavy use and thus be candidates for either clothbound editions or paperbacks that receive additional binding treatments.

Equally problematic is the use of specific price differentials to define what constitutes an excessive price difference between paperback and clothbound editions. The three price differentials analyzed in this work would result in most purchases being made in paperback editions whenever the choice is available. This flies in the face of many academic libraries' predisposition toward clothbound editions. Identifying a specific price differential is also problematic when (a) the price differential is low enough to cause all purchases to be made favoring paperbacks (why have a differential in the first place?) and (b) the price differential does not take into account discipline-specific price variations or control for price increases over time.

Calculating price differences of paperbacks versus clothbound editions as a ratio provides a more effective means for guiding book purchasing decisions. Ratios are more stable over time and are not influenced by price differences across subject disciplines. Employing ratios as a determinant of what constitutes a significant price difference between paperback and cloth editions also provides for greater precision in determining the number of books that are selected in either format. Library directors or collection development managers could employ ratios to determine the percentage of books 
that are acquired in paperback format in general or by subject. Conversely, ratios could be employed to achieve desired cost savings in a specific discipline area by setting the ratio in advance that will trigger a paperback purchasing decision.

Implementing a ratio metric presents some challenges. Approval plans often allow identification of the preferred format for all purchases. Software would have to be created that identified which editions exceeded the desired ratio set by each library for the different disciplines being selected. It is doubtful that vendors would want to engage in such specific identification of materials, especially at the cost of losing clothbound sales. The intangible yet important selection criterion of expected use is also ignored when using an automated approval plan.

Approval plans that require librarians to identify which books are desired from a provided list would support use of a ratio metric as a selection tool. Ratios for each discipline can be easily calculated using a simple spreadsheet program and data from either Choice Magazine or The Chronicle of Higher Education. Once a desired ratio is identified as representing an excessive price difference, a spreadsheet that identifies specific price points and their counterparts calculated using the appropriate ratio for each discipline can be easily used by librarians and other selectors when considering formats for purchase.

An argument could be made that employing ratios is overly deterministic and effectively removes librarians' agency to exercise professional discretion when making book choices. The amount of agency inherent in a collection development policy is a result of the choices expressed and allowed within the collection development statement. Any ratio used will function in a deterministic or advisory role depending on how the collection development statement is framed. The intent is not to create a mechanized and exact system of monograph format selection but instead to ensure that the metric used provides the desired results and not end up favoring that which in principle is least desired.

This study analyzed five different ratios of the paperback to cloth price ranging from 2.5:1 through 3:1. These ratios were arbitrarily chosen. A library that wants to increase or decrease the number of paperbacks considered for purchase would simply use a different number. Actual or anticipated preservation costs can also be factored in when calculating the desired ratio. Regardless of what is selected, ratios represent a more controlled and accurate means of beginning the decision to consider a paperback over a cloth edition.

Ratios analyzed in this study were derived from the prices of dual format books in anthropology, history, political science, and sociology. These findings represent and are limited to a subset of the social sciences. Given the variations in price differentials between paper and clothbound editions that surfaced during the analysis, we ought to expect additional price difference variations across disciplines such as between the humanities and the sciences. Using the average price differential between paper and clothbound editions to calculate a ratio results in an artificial collapsing of true variation since the average is derived from all disciplines. If they are to be employed effectively and accurately, what constitutes a reasonable ratio will need to be calculated for each subject area. There are also disciplines where ratios might not be needed because either most of the books are published in clothbound editions or information in the discipline resides mostly in academic journals. Further research over a longer span of time on price differences between paper and hardcover editions is needed to address these questions.

This study also does not take into account factors that influence purchasing decisions such as the life span of disciplinary knowledge and conditions of expected use. While the stated purpose of this study was to focus on price dif- 
ferentials to the exclusion of other considerations, some disciplines may move toward purchasing mostly paperback editions or e-books based primarily on the rapidly changing information content as in the computer sciences. Future research identifying these issues would contribute to refining collection development efforts in general.

Each discipline has its own subareas where expectations for increased use are common as in methodology texts in the social sciences. Yet how to operationalize the identification of expected use remains a puzzle, especially given the reliance upon both contextual and experiential knowledge sets. Future research in the area of collection development should focus on the identification of tacit knowledge elements useful for collection development for both improving collection development within a library and improving instruction in the area of collection development.

It is easy to critique current practice while proposing alternatives to said practices. Future research needs to focus on institutions that use ratios in making purchasing decisions as part of their collection development programs. Are cost savings achieved using ratios? Is greater control and predictability in managing the collection achieved through using ratios rather than fixed price points as decision criteria, as this study suggests? Do librarians making book selections view such ratios as providing useful guidelines or as being overly mechanistic tools that reduce the art of collection development in ways that are not well received? All of these questions point to lines of inquiry needing attention by future research. A rationale for using ratios has been developed and presented in this study. Future research needs to examine these ideas in situ.

\section{Conclusion}

Paperback editions are becoming viable alternatives to cloth editions as academic libraries move to manage acquisition budgets. Collection development statements include guidelines for paperback purchases but often do so using ambiguous language that provides little principled guidance or employing metrics that are inadequate and that could result in purchasing decisions that appear contrary to the overall collection development thrust of the institution. Establishing and using ratios of price differences between paperback and cloth editions in general or by specific disciplines provides a principled basis for guiding the selection process when a choice needs to be made in terms of format. The analysis presented here provides a clear set of rationales for including ratios as part of an academic library's collection development policy. This analysis also serves as an initial step toward establishing purchase decision ratios in the four disciplines of anthropology, history, political science, and sociology.

\section{Notes}

1. The Bowker Annual, 52nd ed., ed. Dave Bogart (Medford, N.J.: Information Today, 2007), 420-21, table 3.

2. Jim Milliot, "Book Trade Research and Statistics," The Bowker Annual, 52nd ed., ed. Dave Bogart (Medford, N.J.: Information Today, 2007), 469, table 2.

3. Stanley P. Hodge, "The Question of Paperbacks for Academic Libraries: Selection, Treatment Options, and Durability" in Academic Libraries: Achieving Excellence in Higher Education, ed. Thomas Kirk (Chicago: ALA, 1992), 248-56.

4. Milliot, "Book Trade Research and Statistics," 473.

5. Ibid., 481.

6. Barbara Hoffert, “The Paperback Bind," Library Journal 116, no. 2 (1991): 51-55.

7. Joan Stephens, "The Life Expectancy of Paperback Books in Academic Libraries: Eleven Years Later," Technical Services Quarterly 15, no. 4 (1998): 17-25.

8. Stanley J. Slote, Weeding Library Collections: Library Weeding Methods, 4th ed. (Englewood, 
Colo.: Libraries Unlimited, 1997), 24-26.

9. Stephens, "The Life Expectancy of Paperback Books in Academic Libraries: Eleven Years Later," Technical Services Quarterly 15, no. 4 (1998): 17-25; Roger L. Presley and Christina Landram, "The Life Expectancy of Paperback Books in Academic Libraries," Technical Services Quarterly 4, no. 3 (1987): 21-29; Roger L. Presley and Christina Landram, "The Life Expectancy of Paperback Books in Academic Libraries: A Follow-up Study," Technical Services Quarterly 7, no 4 (1990): $1-10$.

10. P. Jenkins, "Some Thoughts on Purchasing Paperback Books for Small College Libraries," College E Undergraduate Libraries 4, no. 1 (1997): 25-28.

11. Alan W. Aldrich, "Following the Phosphorous Trail of Research Library Mission Statements into Present and Future Harbors," Sailing into the Future: Charting Our Destiny: Proceedings of the Thirteenth National Conference of the Association of College and Research Libraries, ed. Hugh A. Thompson (Chicago: Association of College and Research Libraries, 2007).

12. American Library Association, Guidelines for Collection Development (Chicago: American Library Association, 1979).

13. Alan W. Aldrich, "A Typology of Collection Development Decision Metrics," paper presented at the Mountain Plains Library Association annual meeting in Albuquerque, N.M. (2007).

14. Horn Library, Babson College, "Collection Development Policy," Section 2-A (Aug. 18, 2004). Available online at www3.babson.edu/library/research/collection_development_policy. cfm\#16. [Accessed 9 January 2008].

15. Indiana University Kokomo Library, "Collection Development Policy" Section XI-C (Apr. 2006). Available online at www.iuk.edu/ kolibry/docs/COLLECTIONDEVELOPMENTPOLICY. pdf. [Accessed 9 January 2008].

16. Ottenheimer Library, University of Arkansas at Little Rock, "Collection Development Policy," Section VIII-A-7 (May 13, 1997). Available online at http://library.ualr.edu/policies/colldev/colldev.pdf. [Accessed 9 January 2008].

17. The LSU Libraries, "Louisiana State University and A\&M College Collection Development Policy," Section 3-G (1998). Available online at www.lib.lsu.edu/collserv/colldev/policies/g4.html. [Accessed 9 January 2008].

18. MacPhaidin Library, Stonehill College, "Collection Development Policy" (2005). Available online at www.stonehill.edu/library/Acquisitions/colldevpol.htm. [Accessed 9 January 2008].

19. Stewart Library, North Georgia College and State University, "Collection Development Policy," Section VI-B (July 2006). Available online at www.ngcsu.edu/Adminsrv/Library/Collect ion\%20Development\%20Policy\%20July\%202006.pdf. [Accessed 9 January 2008].

20. Edwin H. Mookini Library, University of Hawaii at Hilo, "Collection Development Policy" (2007). Available online at http://library.uhh.hawaii.edu/lib_services/policies/coll_dev_policy.htm. [Accessed 9 January 2008].

21. University of Oregon Libraries, "Collection Policy Statement" (2007). Available online at http://libweb.uoregon.edu/colldev/cdpolicies/cdpstate.html. [Accessed on 9 January 2008].

22. The College of Wooster Libraries, "Collection Development Policy," Section P (Oct. 9, 2006). Available online at www.wooster.edu/LIBRARY/Collection/cdmain.php. [Accessed 9 January 2008].

23. Baylor University Libraries, “Collection Development Policy,” Section G-5 (Oct. 17, 2006). Available online at www.baylor.edu/lib/resourcemgmt/index.php?id=37810. [Accessed 9 January 2008].

24. University of Notre Dame Libraries, "University Libraries of Notre Dame Collection Development Policy: Types and Formats of Materials Collected" (2005). Available online at www. library.nd.edu/colldev/policy/general_policy.shtml\#types. [Accessed 9 January 2008].

25. University of South Carolina Libraries, "Collection Development: General Policies" (2005). Available online at www.sc.edu/library/techserv/cmgenpol.html. [Accessed 9 January 2008].

26. Florida A\&M University Libraries, "Collection Development Policy for the Florida A\&M University Libraries" (June 2005). Available online at www.famu.edu/oldsite/ACAD/coleman/ CDpolicy.htm. [Accessed 9 January 2008].

27. Yale University Collection Development Council minutes. Available online at www.library. yale.edu/CDC/public/minutes/FY00/Minutes021501.html. [Accessed 23 May 2008].

28. Cowles Library, Drake University, "Collection Development Policy" (2004). Available online at www.lib.drake.edu/site/aboutCowles/policies.php. [Accessed 9 January 2008].

29. Colgate University Libraries, "Colgate University Libraries Collection Development Policy" (2003). Available online at http://exlibris.colgate.edu/about/policies/cd_policies.htm. [Accessed 9 January 2008].

30. Trible Library, Christopher Newport University, “Collection Development Policy” (2001). Available online at http://library.cnu.edu/policy.html\#collection. [Accessed 9 January 2008]. 
31. Milliot, "Book Trade Research and Statistics," 473.

32. Houchen Bindery Ltd, Utica, Nebraska, charges $\$ 5.81$ to add a hardcover binding using the original cover art of a paperback edition.

33. Figures obtained on 30 May 2008 from a major east coast bindery that wishes to remain anonymous.

34. Haverford College Libraries, "Haverford College Libraries Collection Development/Management Policy and Bibliographer's Manual," Section II-A (Feb. 1999). Available online at www. haverford.edu/library/about/cdpolicy.pdf. [Accessed 9 January 2008].

35. Emmanuel d'Alzon Library, Assumption College, "Collection Development and Retention Policy" (Spring 2007). Available online at www.assumption.edu/dept/Library/resources/colldevpolicy4-07.pdf. [Accessed 9 January 2008]. 